\title{
MUJERES ARTISTAS E IMAGEN FEMENINA EN ALFAR, REVISTA CORUÑESA DE VANGUARDIA (1922-1926)
}

Isabel Rodrigo Villena

Universidad de Castilla-La Mancha

Data recepción: 2017/11/28

Data aceptación: 2018/04/03

Contacto autora: isabel.rodrigo@uclm.es

ORCID: https://orcid.org/0000-0002-3762-1260

\section{RESUMEN}

La revista de vanguardia Alfar, dirigida en A Coruña por Julio J. Casal entre 1923 y 1926, realizó una proyección inusual de la creación femenina, difundiendo la obra de poetisas, novelistas, compositoras, pintoras y escultoras, en un número exiguo, pero proporcionalmente superior al de la mayoría de las publicaciones de su tiempo y estilo. Este artículo presenta a las seis artistas plásticas que pasaron por sus páginas: Norah Borges, Sonia Delaunay, Angelina Beloff, Aida Uribe, Laura Olmos y Laura Rodig. Las sitúa en los dos momentos estéticos de la revista: el ultraísmo inicial y el llamado "retorno al orden" o nuevo clasicismo, a partir de 1924. Y analiza su acogida en relación a las ideas sobre la mujer y sobre la creatividad femenina propias de la vanguardia española de la época.

Palabras clave: Alfar, mujeres artistas, crítica de arte, vanguardia, estudios de género

\section{ABSTRACT}

The avant-garde journal Alfar, which was edited in A Coruña by Julio J. Casal between 1923 and 1926, contributed to the visibility of female creativity to an extent quite rare at the time, by devoting some of its pages to the work of female poets, novelists, composers, painters and sculptors. Although it focused on only a few female artists, their number was proportionally much higher than in other publications of the same period and style. This paper presents the six visual artists that appeared in its pages: Norah Borges, Sonia Delaunay, Angelina Beloff, Aida Uribe, Elena Olmos and Laura Rodig. It situates them within the journal's two aesthetic phases: its initial Ultraist phase and the "return to order" or new classicism, from 1924. The paper also analyses how the artists were received in terms of the ideas that the Spanish avant-garde of the time held about women and female creativity.

Keywords: Alfar, women artists, art critic, avant-garde, gender studies

Por minúsculas y efímeras que parezcan, las revistas de vanguardia fueron fundamentales en la difusión de lo nuevo en una España que iba con retraso y era reticente a las novedades'. Entre las muchas que aparecieron desde la pionera Prometeo, este trabajo está dedicado a la revista coruñesa Alfar (1922-1926), de la que existe una edición facsímil2, supervisada y comentada por César Antonio Molina³, con un estudio estético de Juan Manuel Bonet, y un trabajo fundamental que explica los orígenes de su creación y su trayectoria literaria, a cargo de Victor G. de la Concha ${ }^{4}$.

Se trata de una revista de transición entre las publicaciones ultraístas, donde Gloria Videla sitúa a: Cervantes, Cosmópolis, Ultra, Ultra de Oviedo, Tableros, Perseo, Vértices, Tobogán, Reflector, Horizonte y Españas, y las que Juan Manuel Rozas ha 
llamado la "edad de oro de las revistas del 27"6, con Mediodía, Litoral, Papel de Aleluya, Verso y Prosa, Carmen y Gallo como publicaciones fundamentales. Periférica a unas y a otras, contó entre sus redactores e ilustradores a poetas y artistas afines al ultraísmo cuando el movimiento ya se daba por finiquitado, y fue portavoz del llamado "retorno al orden" en las artes, y de los poetas y prosistas que después acabarían integrando la Generación del 27.

El proyecto se debe a la labor filantrópica del poeta uruguayo Julio J. Casal, cónsul en A Coruña entre 1913 y 1926, quien primero fundó la revista Vida (1920-1921), asumiendo en 1922 la dirección del boletín Casa América-Galicia, creado en diciembre de 1920 por la asociación hispanoamericana del mismo nombre, con el fin de mantener vínculos laborales y comerciales entre los emigrados y sus países de origen, en el marco del floreciente intercambio comercial y auge migratorio entre España y América. Bajo el influjo de Casal, quien le añadió el sobrenombre Alfar en octubre de 1923, después de haber pasado por otras denominaciones? , el antiguo boletín se convirtió en una revista cultural y de creación de gran calidad que, durante casi cuatro años, estará atenta y dará cuenta de las corrientes más renovadoras españolas, gallegas y de ultramar. El regreso del poeta a Uruguay anunciaba su cierre en el número 60 (agosto-septiembre de 1926), reactivándola en Montevideo donde se publicó, siempre abierta a la colaboración de los exiliados españoles, desde 1929 hasta su muerte en 1954.

De las tres etapas de la revista, trataremos en este artículo de la época coruñesa dirigida por Julio J. Casal (1922-1926), centrándonos fundamentalmente en el ámbito artístico, para analizar un aspecto escasamente tratado en la historiografía de las revistas de vanguardia: la recepción de las mujeres artistas. De acuerdo con el carácter de transición ya comentado, veremos en Alfar a pintoras activas en las vanguardias, junto a otras que apostaban o recuperaban las formas clásicas.

\section{Alfar: un espacio para el arte y la creación femenina}

A diferencia de sus antecesoras ultraístas, Alfar fue una revista cultural más completa y generalista; una miscelánea que pretendía abarcar la producción intelectual en su conjunto, aunque concediera un espacio importante a la literatura ultraísta y exultraístå. La parte artística y gráfica, dirigida por el pintor uruguayo Rafael Barradas, la pusieron sus portadas, las páginas ilustradas y los ensayos críticos sobre arte y artistas de actualidad. No se hizo, sin embargo, un seguimiento o crónica de exposiciones continuada, ni existió la figura de un crítico asiduo con sección constante. Quienes más escribieron sobre arte fueron el crítico madrileño Manuel Abril, el escultor Ángel Ferrant, que se dio a conocer como teórico en una sección llamada "El escultor y su área" continuada a lo largo de siete números, y el crítico y pintor polaco refugiado en España, Marján Paszkiewicz. El resto fueron colaboraciones ocasionales de Juan de la Encina, Guillermo de Torre, Humberto Pérez de la Ossa y hasta casi una veintena de autores ${ }^{10}$ que defendieron, según los casos, el ultraísmo inicial durante los años 1922 y 1923, y el "regreso al orden" en sus diferentes versiones, a partir de 1924.

En ambos extremos situamos a las seis mujeres artistas sobre las que Alfar dio noticias durante sus cuatro años de tirada coruñesa: Norah Borges, Sonia Delaunay y Angelina Beloff, exponentes de la vanguardia; y representando al clasicismo y la nueva figuración: Elena Olmos, Aida Uribe y la escultora Laura Rodig. El número es absolutamente irrisorio, y pese a ello, debe decirse que Alfar fue una de las publicaciones de vanguardia más atentas a la creatividad femenina en comparación con la mayoría de sus homólogas, en algunas de las cuales la mujer artista, e incluso la mujer escritora, estuvieron ausentes. La coruñesa, sin embargo, no solo se hizo eco de los trabajos plásticos de las artistas citadas; también refirió su quehacer en la música publicando partituras para piano y un artículo crítico sobre la compositora y pianista Carmen Barradas; y describió la aportación a la poesía, al teatro y a la novela nacional e internacional, de casi una veintena de escritoras españolas e iberoamericanas. En concreto, publicaron poemas o prosas en Alfar, las autoras: Juana de Ibarbourou, Norah Lange, Helena M. Murguiondo, María Clemencia López-Pombo, María del Carmen Izcua, Luisa Luisi, Mercedes Pinto, Josefina de la Torre, María Luisa Iriarte, María Eugenia Iribarren, Gabriela Mistral y Concha Espina. Sobre esta última, Humberto Pérez de la 
Ossa publicó una crítica de su obra El cáliz rojo. Se publicó también un texto de F. Martínez Mora llamado "La mujer gallega", que hablaba de Rosalía de Castro, Concepción Arenal y Emilia Pardo Bazán, y otro sobre la novelista peruana Angélica Palma, por Luis Antonio de Vega. Guillermo de Torre escribió, además, sobre poetisas argentinas, centrando su interés en las tres que consideraba epígonos de su generación más joven y vanguardista: Helena M. Murguiondo, María Clemencia López y Norah Lange.

\section{Ultraísmo femenino en Alfar}

Estas tres poetas del ultraísmo argentino, colaboradoras de sus publicaciones fundamentales (Prisma, Proa y Martín Fierro), nos acercan a la figura de Norah Borges, y con ella a la plástica ultraísta. En el texto citado, Guillermo de Torre aclaraba que las tres se habían formado bajo su égida y que "el plural fervor estético" de la pintora, había "prendido en el alma" de las "aurorales poetisas" $"$.

Hablar de la pintura ultraísta es hablar de Norah Borges y, cómo no, de Rafael Barradas. La participación de ambos y de otros pintores vinculados al grupo (Francisco Miguel, Luis Huici y Francisco Bores) fue lo más ultraico de Alfar, si seguimos el análisis propuesto por Eugenio Carmona ${ }^{12}$. Ellos se ocuparon de diseñar la gráfica, de ilustrar sus páginas -que combinaban grabado y texto en clara relación entre el contenido visual y literario-, y de decorar sus portadas con motivos ultraístas hasta finales de 1923. De éstas, Barradas habría realizado las menos arriesgadas, formadas por una sencilla xilografía que adornaba el nombre de la revista escrito en letra natural ${ }^{13}$, así como de una veintena de dibujos, caricaturas de intelectuales en su mayoría. Uno de sus retratados, el crítico Manuel Abril, defendió su apuesta vibracionista en un artículo publicado en el número 27, en marzo de 1923. Dos de las portadas de más claro estilo ultraísta, con ecos futuristas y expresionistas ${ }^{14}$, las realizó el coruñés Francisco Miguel (fig. 1). El malogrado pintor, asesinado al principio de la Guerra Civil tras regresar de una estancia de siete años en México ${ }^{15}$, publicó también varios grabados y linóleos ultraístas entre 1922 y 1923. Los linóleos de su amigo Luis Huici, el llamado "artista sastre", porque compagina-

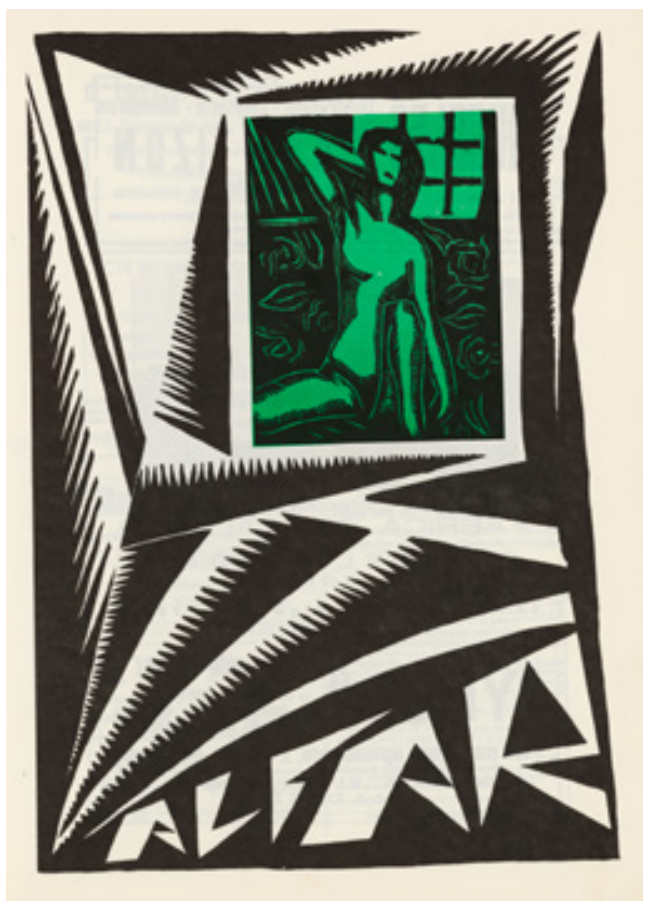

Fig. 1. Francisco Miguel. Portada de Alfar, n³3, 1923. Fuente: Universidad República de Uruguay

ba ambas profesiones, además de la militancia republicana que le llevaría como a él al paredón, también contribuyeron a dar un toque ultraísta a la revista a finales de 1922 y a lo largo de 1923, con obras como Ritmo flamenco; como también algunas xilografías de Francisco Bores, autor que llegó tardíamente al grupo, vivificándolo y siendo nexo de unión entre el "arte nuevo" y el "regreso al orden" ${ }^{\prime 1}$.

Entre estos artistas, el caso de Norah Borges inicia la historia femenina del ultraísmo plástico. Antes de describir con más detalle su aportación gráfica a la revista y cómo fue recibida por los críticos en sus páginas, debe aclararse que su paso por el ultraísmo como mujer artista, no fue del todo excepcional, que la participación femenina en la escasamente representada plástica ultraísta incluyó también a otras pintoras y escultoras, dotando al movimiento de un número casi paritario de hombres y mujeres artistas, entre los que estuvieron, tomando como fuente las descripciones del grupo realizadas por Guillermo de Torre en las revistas Cosmópolis ${ }^{17}$ y Ultra ${ }^{18}$, y en su libro 


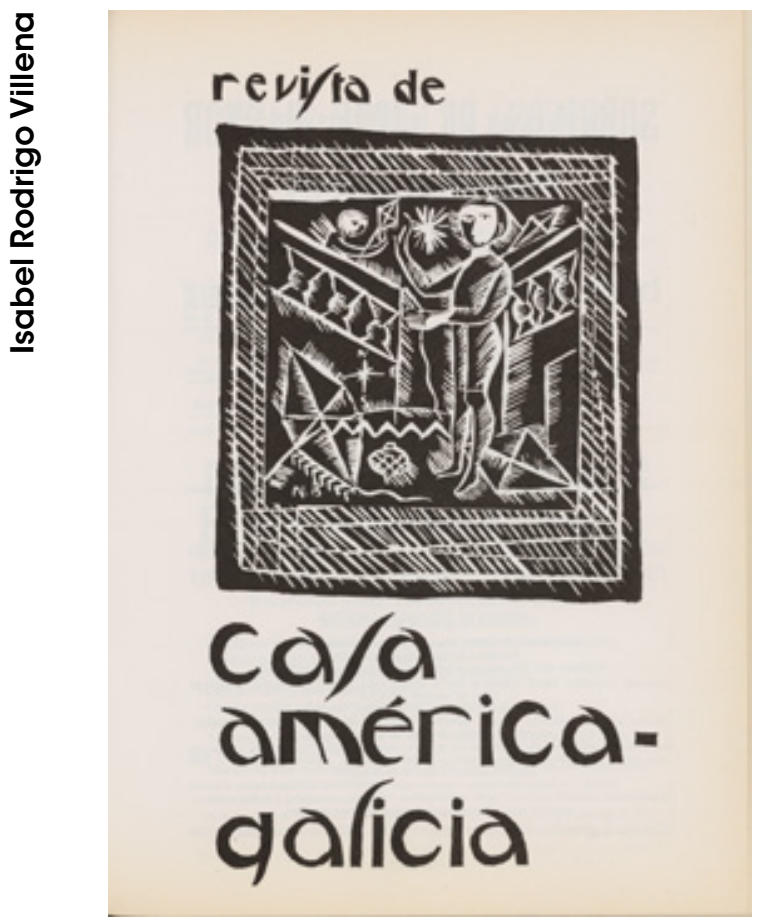

Fig. 2. Norah Borges. Portada de la Revista Casa América-Galicia, n²7, 1923. Fuente: Universidad República de Uruguay

Literaturas Europeas de Vanguardia (1925)19, los siguientes artistas: Rafael Barradas y Norah Borges como figuras fundamentales en la pintura y la xilografía, especialidad en la que también destacaron Francisco Bores y Wladyslaw Jalh; los jóvenes Santiago Vera y Ruth Velázquez, por el uso del llamado "color noviestructural" 20, plástico y sensual a la vez; Daniel Vázquez Díaz, cuya ascensión colorista se había podido ver en la segunda exposición ultraísta celebrada en los salones de "La Parisina"; y un único caso en el ámbito de la escultura: el de Eva Aggerholm. En las proximidades del ultraísmo, Guillermo de Torre situó asimismo a Sonia Delaunay, según declaraciones realizadas en Alfar que después comentaremos; y en el terreno musical, a la compositora Carmen Barradas ${ }^{21}$. Sobre esta última, Juan G. del Valle y G. de la Vega resaltaron en Alfar su "sensibilidad para captar la belleza de la disonancia" y para dar hechura musical a hechos aislados derivados de sensaciones directas, como en las piezas Fundición, Aserradero o Fabricación ${ }^{22}$, cuya emulación de sonidos industriales tenían ecos futuristas ${ }^{23}$.
Volviendo a Norah Borges (Buenos Aires, 1901-1998) -como la bautizó su hermano Jorge Luis Borges, porque en realidad se llamaba Leonor Fanny-, su aportación gráfica en Alfar fue numéricamente similar a la del propio Barradas, aportando la ilustración de una portada (fig. 2) y casi una docena de linóleos y grabados. Se publicaron, además, dos textos críticos explicando su original aportación, que después comentaremos. La artista había llegado a España junto a su familia, en 1919, instalándose en Sevilla, después de haber pasado un tiempo en Mallorca, donde estudió con el pintor sueco Sven Westman, y de haber realizado un revelatorio viaje a Córdoba que la acabaría llevando al estudio de Romero de Torres en Madrid24. Según Adriano del Valle, quien se atribuyó el honor de haber descubierto a la "hermosísima perla intelectual" 25 que fue para él Norah Borges, el contacto con el grupo ultraísta se produjo en el Centro de Estudios Teosóficos, cuando el poeta ofrecía una conferencia literaria a la que acudió la familia Borges en pleno. Como no estaba bien visto que una mujer frecuentara los cafés y las tertulias masculinas, su relación con los ultraicos se hizo desde la distancia y gracias a la intermediación de su hermano Jorge Luis y de su futuro novio y marido, Guillermo de Torre ${ }^{26}$. El primero la habría parapetado para asistir a algunas reuniones con el grupo sevillano, y a través del segundo -según explicó ella misma en una entrevista a Juan Manuel Bonet ${ }^{27}$-, enviaba sus colaboraciones a las revistas.

No conoció, por tanto, a la mayoría de los miembros del ultraísmo y sin embargo, salvando estas y otras resistencias impuestas a las mujeres, Norah Borges fue, junto a Barradas, una de las artistas más activas del grupo. Sus xilografías ilustraron casi todas las revistas del movimiento (Grecia, Reflector, Ultra, Tableros, Horizonte, etc.), el "Manifiesto Ultraísta Vertical", y algunas de las publicaciones que fueron epígono del mismo y transición a la Generación del 27, entre ellas: Ronsel, también gallega; Ambos, Plural, etc. Para los poetas del Ultra, Norah Borges fue una auténtica revelación, dedicándole poemas y textos exaltados que reconocían su aportación plástica al ultraísmo. En uno de ellos, publicado en la revista Grecia por su director, Isaac del Vando Villar, pudo leerse: "Hermanos del ultra: Norah Borges es nuestra pintora" 28 , resaltando su capa- 
cidad intuitiva y de captación de la esencia de las cosas, su fantasía temática y su valentía para desdeñar las leyes tradicionales. En la misma revista -y después lo haría en Cosmópolis29- Guillermo de Torre explicaba que la argentina sintonizaba con el ultra "por el ansia de su avidez innovadora [...]. Por su apasionamiento de las planimetrías inéditas [...]" 30, y la comparaba con otros pintores modernos (Cezanne, Marc, Kandinsky, Gaugin y los grabadores Ossip Zadkin, Morin Jean y Galanis, etc.) y con las artistas Marie Laurencin, María Blanchard, Natalia Goncharova, Irene Laguy y Angelina Beloff. Para el escritor, todas ellas, y en particular Norah, eran una excepción entre las mujeres artistas:

¡Oh, Norah! ¡Frente a las féminas, sólo superficie, que cultivan el «sport» del dibujo decorativo, las transcripciones museales o los acuarelismos delicuescentes, tú sola te elevas sideralmente, $y$ te adentras al dintorno de las introspecciones pictóricas, subjectivizando vitalmente la objetiva realidad yerta, y persuadiendo a la materia hasta revelárnosla en su más recóndita belleza! ${ }^{31}$.

Las colaboraciones de Norah Borges en Alfar se enviaron desde su Argentina natal, donde la pintora había regresado con su familia en 1921. Las publicadas entre 1923 y 1924 eran todavía ultraístas, aunque la artista, condicionada por un ambiente menos vanguardista que el vivido en Madrid en 1920, en esa época hubiera vuelto ya al color y a los temas de ángeles, sirenas y amantes que la caracterizarían desde entonces. Nos referimos a las maderas y linóleos que aparecieron publicados sin título en los números 27 , 28,32 y 33 -incluyendo la portada del primero, que identificamos por sus iniciales (fig. 2); y a los llamados: Ajedrez (fig. 3), Urbano y Simona y Venus y Cupido, que aparecieron en el 36, el 39 y el 44, respectivamente. En cambio, el grabado Aldeanas de Lugo, que ilustraba el número 49 de 1925, tenía ya un resabio clasicista que la alejaba del ultraísmo y anunciaba la estética de la Generación del 27.

La recepción crítica de Norah Borges en Alfar la pusieron dos textos de Guillermo de Torre y de Manuel Abril, publicados respectivamente en 1923 y 1924. El primero era una semblanza breve llamada "Retrato", que apenas añadía pequeños matices a lo ya escrito de ella en Grecia y Cosmópolis. Gui-

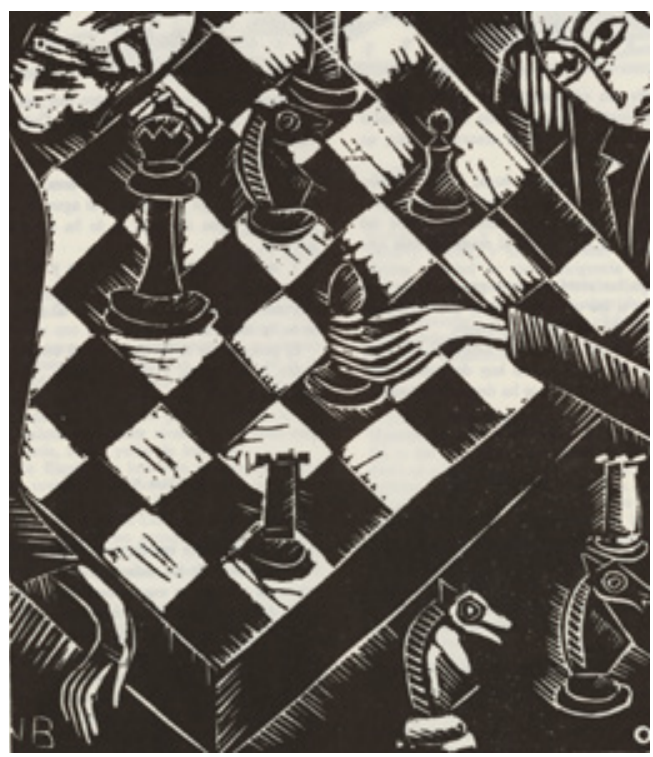

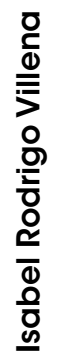

Fig. 3. Norah Borges. Ajedrez. Revista Alfar, $n^{\circ} 36,1924$. Fuente: Universidad República de Uruguay

llermo de Torre, novio formal de la pintora en esa fecha, recordaba su ascendencia expresionista, herencia de su formación en Ginebra; su adhesión al constructivismo cubista, del que decía estar ya de vuelta; e insistía en la feminidad de su obra candorosa, ingenua y emotiva ${ }^{32}$, para dejarla al margen de las modernas garçonnes ${ }^{33}$. Sobre dicha relación, que nunca fue del agrado de Jorge Luis porque la iba alejando de sus raíces más expresionistas reconduciéndola hacia el "nuevo romanticismo" ${ }^{34}$, decía también en Alfar: "-Si, en efecto, Norah Borges ilumina ahí en frente como un reflector cordial, todas mis horas de pensamiento y de trabajo, pero no, no espere usted confidencias de índole erótica. Quizá en mi novela "El meridiano adolescente" haya algunos capítulos esclarecedores..." 35.

El texto escrito por Manuel Abril era más distanciado y objetivo. Llamado "La dama del ajedrez" ${ }^{36}$, ponía palabras al grabado del mismo título que lo acompañaba (fig. 3). Para el crítico del arte nuevo, Norah Borges mezclaba imágenes a su voluntad, como en un juego de naipes que ella barajaba a su antojo. Establecía paralelismos entre su trabajo y el ajedrez por el orden arbitrario y los contrastes entre el marfil y el ébano recurrentes en la artista, explicando que su talento era plantear mil combinaciones, "trenzados infinitos" y "cambiantes inéditos", sin 


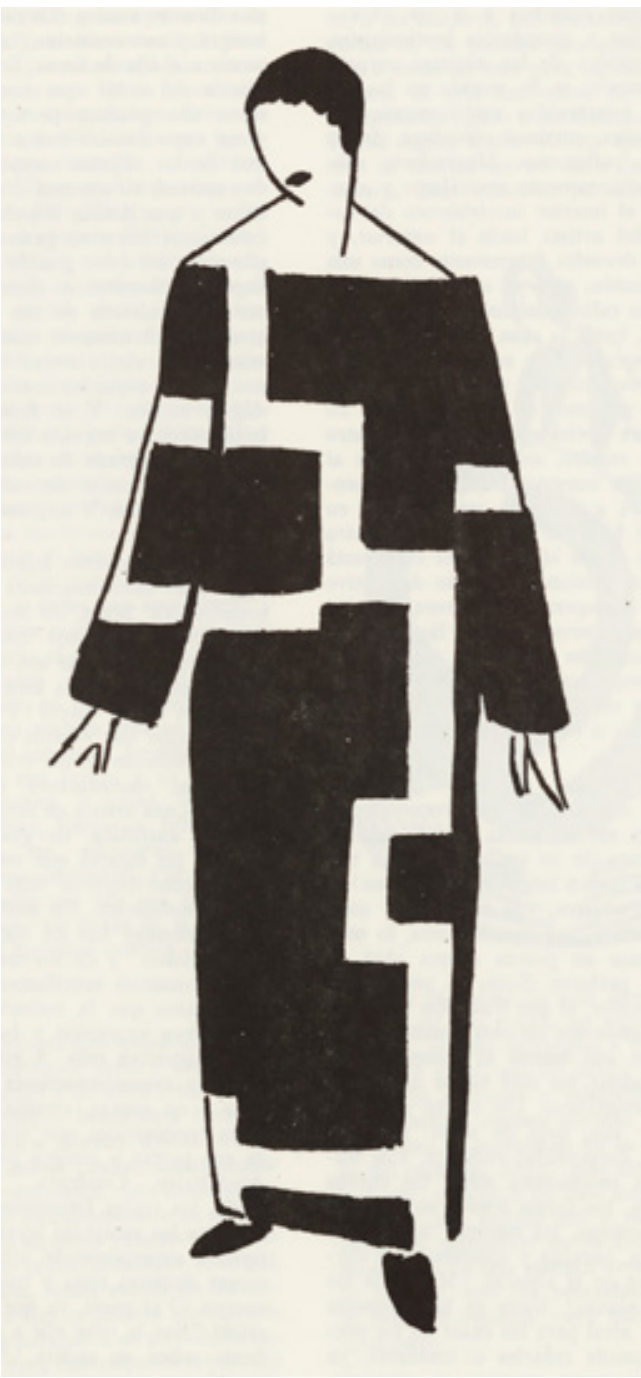

Fig. 4. Sonia Delaunay. Dibujo. Revista Alfar, n³5, 1923. Fuente: Universidad República de Uruguay

"pisar la raya", desplegando fantasía pero ateniéndose siempre al blanco y negro y a la cuadrícula.

Representando también a las vanguardias, y en cierto modo al ultraísmo, la segunda mujer publicitada en Alfar fue la pintora de ascendencia rusa Sonia Delaunay (Odesa, 1885-París, 1979), de quien se escribió un artículo referido a su segunda etapa madrileña, cuando fundó "Casa Sonia" ${ }^{37}$ para aplicar los principios del simultaneísmo al mundo de la decoración y el diseño de

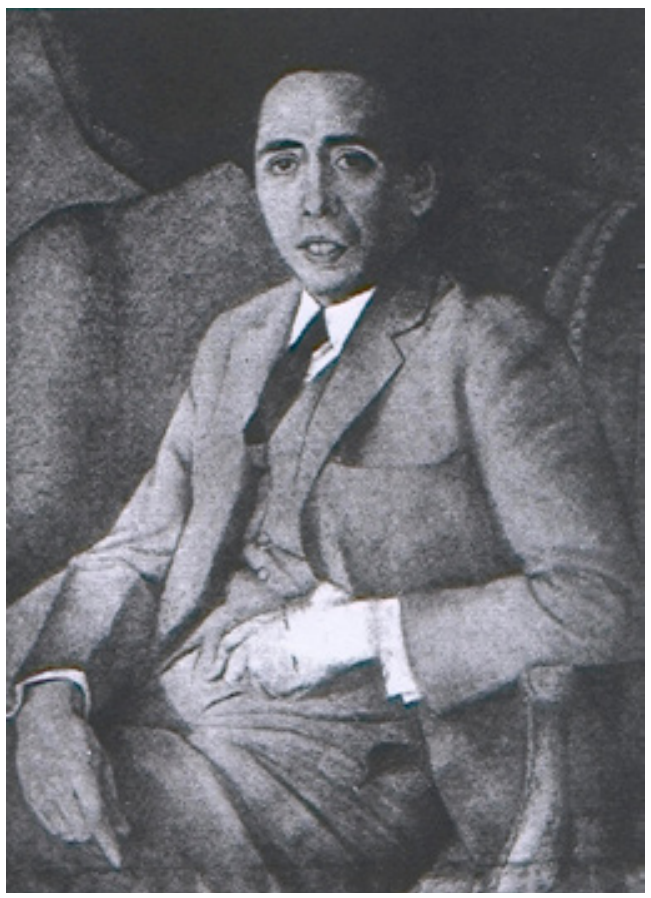

Fig. 5. Angelina Beloff. Retrato de Oliverio Girondo. Revista Alfar, $n^{\circ}$ 50, 1925. Fuente: Universidad República de Uruguay

moda. Sobre su participación en Alfar existe un artículo de S. Cendán ${ }^{38}$.

El interés por la pintura de Sonia Delaunay fue realmente discreto en la crítica española de la época, eclipsada por la de su marido Robert Delaunay y quizás por la de Norah Borges. Su nombre se había leído en Grecia, apenas esbozado en un poema donde Isaac del Vando la declaraba portavoz del arte nuevo: "En los espejos de tu cara, el arte nuevo nos sonríe" 39 -decía-; y en el "Álbum de retratos. Mis amigos y yo", de Guillermo de Torre, quien la recordaba conjuntamente con su marido "contemplando maravillados el arco iris inaugural en que los colores parecen purificados..." 40 .

Sonia Delaunay no fue incluida en el sumario ultraísta de las Literaturas Europeas de Vanguardia y, pese a ello, Guillermo de Torre la consideró ultraísta, defensora y estandarte del arte nuevo; pero del arte nuevo útil, del lanzado a la calle. Así lo afirmaba en su artículo de Alfar: "El arte decorativo de Sonia Delaunay-Terk", firmado en 1923, cuando la artista ya había regresado a París tras 
el paréntesis de la Guerra Mundial que la trajo a la Península. Acompañado de un dibujo de la autora a página completa (fig. 4), en él describía pormenorizadamente su aplicación de la plástica simultánea a sombreros, muebles, cubiertas de libros, decoraciones teatrales y renovación de locales -citaba el vestuario diseñado para el ballet ruso de Diaghilev y sus intervenciones en el Petit Palais de Madrid, entre otros proyectos-, y trazaba su recorrido, sus influencias y sus méritos, con una equidad y seriedad en nada comparable a la imagen burlesca que ofreció de ella CansinosAssens en su novela satírica sobre el grupo: El movimiento V.P. (1921), donde la imaginaba en la cocina fabricando sus pigmentos con rábanos y zanahorias, bajo el sobrenombre de Sofinka Modernuska ${ }^{41}$. Por el contrario, Guillermo de Torre le reconocía su importante contribución en la definición inicial del cubismo y en la creación del orfismo y del simultaneísmo:

Sonia no es una obrera hábil que movida por el industrialismo, o respondiendo a un criterio de buen gusto instintivo, manufacture productos artísticos. Sonia es una artista de noble ejecutoria. Es una pintora auténtica, de gran temperamento, y una de las figuras que en los albores del cubismo contribuyeron más a la definición de aquel movimiento. En unión de su marido Robert Delaunay fue en 1909-1912, la creadora del "orfismo" y de los contrastes simultáneos ${ }^{42}$.

El texto sobre Delaunay era también un alegato a favor del arte decorativo. Frente al descrédito que sufría la especialidad entre algunos críticos de la vanguardia, Guillermo de Torre reconocía su importancia intelectual y creativa, destacando el carácter "altruista" de Sonia por "crear una belleza útil y necesaria" en lugar de haberse quedado en el esoterismo y la esterilidad de la pintura abstracta cubista; reconociéndole, a su vez, haberlo hecho con un estilo tan genuino que no dudaba en llamar "sonianas" a sus decoraciones, caracterizadas por integrar los signos de una nueva época, con su dinamismo, colores y contrastes simultáneos, aclimatando lo oriental a lo occidental y lo cosmopolita a lo popular. Las siguientes palabras expresan el entusiasmo del crítico hacia la propuesta colorista de Sonia:

El color no vive ya aprisionado entre los cuatro barrotes de un cuadro [...]. El color está en libertad y su prisionero, el arte decorativo tradicional, se despereza y oscurece. ¿Quién ha sido el hada generosa que con las solas llaves de sus manos ha abierto la prisión, dejando que se desparramen los colores en nuestras casas y en nuestro indumento, como una bandada de niños o de pájaros? Sonia Delaunay-Terk ${ }^{43}$.

La última de las artistas de vanguardia presentes en Alfar no fue ultraísta. En realidad, no toda la vanguardia fue ultraísta en la revista coruñesa. Algunos críticos teorizaron sobre el cubismo, entre ellos Marján Paszkiewicz con su escrito "La superficie intacta" (número 37, 1924); y pasaron por sus páginas artistas cubistas y próximos al movimiento como Juan Gris, sobre el que escribió Manuel Abril y fue autor, él mismo, del texto "Las posibilidades de la pintura" (número 43, 1924); el escultor ruso Ossip Zadkine o el escultor brasileño Victor Brecheret.

La artista a la que nos referimos, la dibujante y aguafortista rusa Angelina Beloff (San Petersburgo 1879-México D.F. 1964), también pasó por una fase de experimentación cubista, aunque para la época en que Alfar publicó su Retrato de Oliverio Girondo (fig. 5), para ilustrar una semblanza del poeta argentino en el número 50 de 1925, practicaba ya la nueva figuración, dentro de un estilo que no se atiene a fácil clasificación. Nos referimos a ella en el grupo de las vanguardistas por los contactos que estableció Guillermo de Torre entre su obra y la de Norah Borges, al practicar la primera el aguafuerte y el aguatinta sobre metal (fig. 6), y esta última la xilografía; ambas especialidades rudas y aparentemente poco femeninas que ejercían con valentía, encanto y feminidad, según el autor. Sus titubeos con el cubismo y otras vanguardias coinciden con sus años en París, donde conoce en el taller del español Anglada Camarasa a su gran amiga María Blanchard, y a través de ella, al que sería su esposo, Diego Rivera, entrando en contacto también con Picasso, Juan Gris y otros intelectuales y artistas españoles ${ }^{44}$. La proclamación de la Primera Guerra Mundial sorprendió a la pareja en un viaje a Mallorca, residiendo en Madrid por varios meses durante 1915. Ramón Gómez de la Serna describió el paso del matrimonio de artistas por la emblemática tertulia del Pombo. Según el escritor, él contaba cosas de México y ella de su 


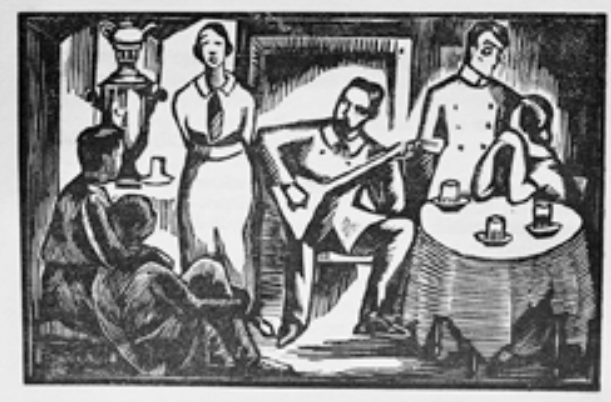

Fig. 6. Angelina Beloff. La vie à deux, 1920. Colección Andrés Blaisten

pasado en Rusia y de sus veranos en Finlandia. Beloff le reveló que su inclinación al aguafuerte era un recuerdo del duro clima, de la luz de la nieve y del gris de aquellas tierras. Ramón la describía como una mujer "incógnita, silenciosa, bajo un delicado velo casi siempre -un velo que iba muy bien a su espíritu". Era "la delicadeza trabajando la materia más dura y viril". Su obra contrastaba con

[...] su ser dulce y débil, de voz delicada -a la que da un tono herido el que la emanación de los ácidos que trabajan las planchas del aguafuerte la ha atacado la garganta-, de ojos azules, de perfil fino y suavemente aguileño, toda ella delgada y vestida de azul -jersey azul en la casa y en la calle traje azul de líneas resueltas-, tan azul todo en ella, tan envolventemente azul, que por eso, además de por su perfil, se la podría llamar el pájaro azul45.

\section{Pintoras de la nueva figuración: Uribe, Olmos y Rodig}

Junto a las artistas modernas, las tres mujeres que mejor representaron en Alfar la desarticulación de las vanguardias y su sustitución por las nuevas figuraciones en sus distintas vertientes, al hilo de lo que también ocurría en Europa con el Novecento italiano y la Nueva Objetividad alemana, fueron Aida Uribe, Elena Olmos y Laura Rodig.

La liquidación de las vanguardias y el proceso de "retorno al orden" fueron tomando presencia en Alfar a lo largo de 1924. Los cambios más aparentes, además del diseño de sus portadas, que dejaron atrás los motivos ultraicos para dar al número de la revista -sobredimensionado y con

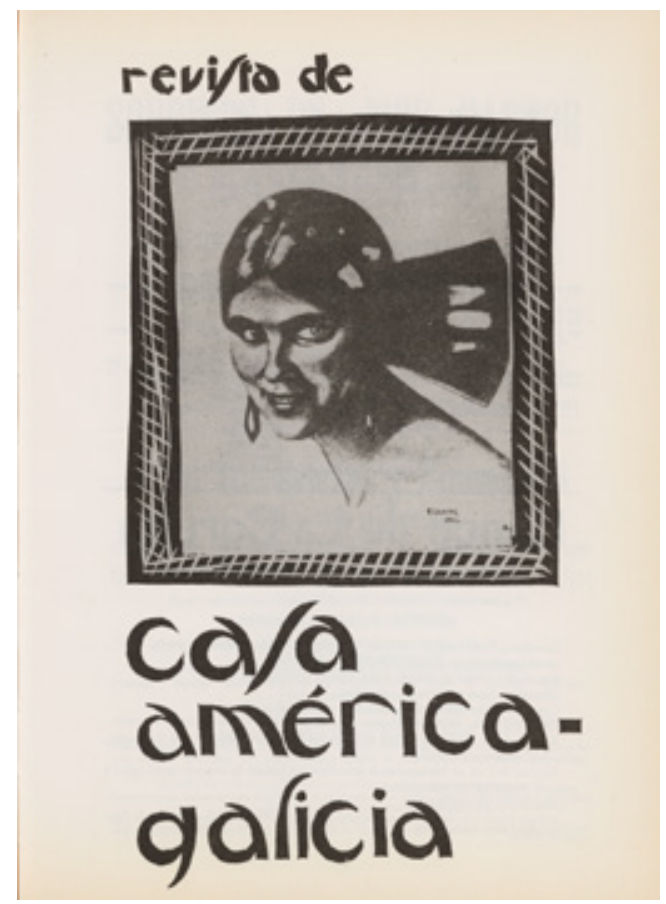

Fig. 7. Elena Olmos. Retrato. Portada de la Revista Casa América-Galicia, $n^{\circ} 24,1922$. Fuente: Universidad República de Uruguay

aire racionalista46-, el protagonismo principal, los tenemos en el giro estético de los artistas que antes habían puesto la nota ultraísta: Francisco Bores, Francisco Miguel, Norah Borges y su propio director artístico: Rafael Barradas, cuyos dibujos de sus paisanos de Luco de Jiloca mostraban una peculiar reconsideración del clasicismo ingresco picassiano ${ }^{47}$, que tuvo que ser defendida por un nuevo artículo de Manuel Abril, publicado en el número 49 (abril, 1925).

La nueva orientación estética de la revista supuso también la difusión de nuevas figuras artísticas entre las que estaban, además de las mujeres citadas, de quienes hablaremos a continuación, autores ya consolidados, como el escultor José de Creef; otros como Victorio Macho y Mateo Hernández, que sin haber estado en contacto con las vanguardias se acercaban al nuevo clasicismo; artistas jóvenes, entre ellos García Maroto, Gregorio Prieto y Salvador Dalí; y por último, autores que mantenían las referencias figurativas aprovechando del cubismo cierta depuración técnica, 
como Joaquín Sunyer y un Daniel Vázquez Díaz muy alejado de su retrato cubista de Picasso de 1922.

Volviendo a las mujeres, una de nuestras artistas, Aida Uribe, paisajista guatemalteca asentada en Madrid y en Guipúzcoa ${ }^{48}$, fue citada en Alfar por su participación en la primera exposición de la Sociedad de Artistas Ibéricos (S.A.I.) celebrada en el Parque del Retiro de Madrid en mayo-junio de 1925; un evento al que la revista dedicó el número 51 casi completo, donde incluyó su Manifiesto y comentarios entusiastas de Juan de la Encina y del periódico El Sol, y que suponía su adhesión más firme al nuevo clasicismo. Dicho manifiesto no contenía firmas femeninas, y sin embargo, sabemos que participaron activamente en una o más exposiciones del grupo las escultoras Margarita Sans Jordi y Eva Aggerholm, y las pintoras Ángeles Santos, Clotilde Fibla, Rosario de Velasco, Lola de la Vega, Marisa Pinazo, Marisa Roësset, María Blanchard, Teresa Condeminas, Carmen Cortés, Margarita Frau, Maruja Mallo, Roberta González, Gabriela Marjorie de Pastor, Marisa Pinazo, Irene Narezo y las pintoras de Alfar: Norah Borges y Aida Uribe.

Del giro estético de Norah Borges y de su participación en la primera exposición de los Ibéricos, Alfar no hizo ya ningún comentario en su etapa coruñesa. A la paisajista Aida Uribe, la citaba solamente en la relación de artistas que participaron en el evento, según los datos recuperados del periódico El Sol. Siguiendo esta fuente, su trabajo se habría visto en una sala contigua a la principal, donde habían reunido a los que todavía no tenían obra suficiente para mostrar grandes series, caso también de Zelaya, Fernández Balbuena, Berdejo Elipe, Sancho Cortés, Ascot o Peinado49. A diferencia de lo escrito por Pérez Segura en su estudio de la S.A.I., donde se afirma que Aida Uribe solo colgó un paisaje que no se ha podido identificar ${ }^{50}$, Francisco Alcántara escribía en El Sol que la autora expuso cuatro paisajes "de laderas verdes y arbolados bañados en luz" 51, acordes a la renovación estética del movimiento; una apuesta que no era incompatible con su participación en las más conservadoras Exposiciones Nacionales de Bellas Artes, donde el año anterior había presentado dos paisajes que la crítica encontró "brillantes de colorido y sim-

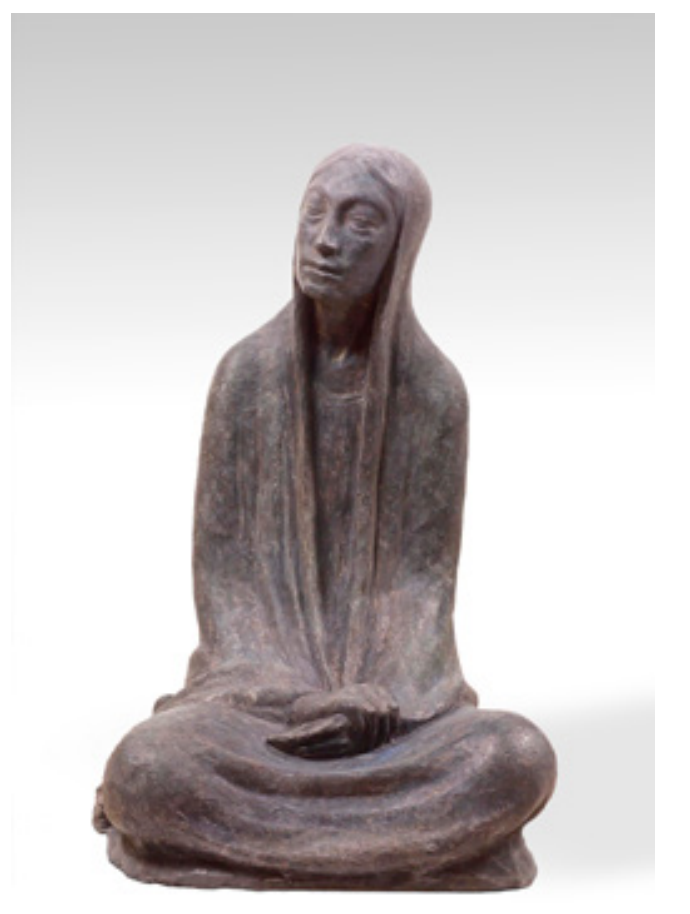

Fig. 8. Laura Rodig. India mexicana. Vaciado en escayola patinada. MNCARS

ples de factura"52. La prensa y los catálogos de exposiciones de esos años la sitúan también en el Círculo de Bellas Artes de Madrid en 1918; en el IV Salón de Otoño de 1923, donde presentó dos paisajes vascos, un bodegón y el apunte de unas barcas; y en el Lyceum Femenino de Madrid en 1927, de cuya muestra escribió Antonio Espina en la Gaceta Literaria, que no había ningún gran acierto en su técnica, pero sí una energía delicada en sus apuntes de naturalezas muertas, algunos con ciertos toques puntillistas ${ }^{53}$.

Otra de las artistas que representaron en A/far la apuesta por una figuración más tradicional fue Elena Olmos Mesa (A Coruña, 1899 - Buenos Aires, 1983), hija del cónsul de Argentina en A Coruña (Manuel Olmos de Aguilera), que acabaría exiliada en el país paterno junto a su esposo, el político Leandro Pita Romero. En realidad, Elena Olmos no venía de retorno. Tras sus estudios en Inglaterra y varios viajes a los Países Bajos que le permitieron conocer a los maestros flamencos, fue formada en Madrid por Sotomayor y Bene- 
dito ${ }^{54}$, realizando desde sus inicios una pintura realista, de un regionalismo no estricto porque también pintó tipos belgas e italianos y retratos de mujeres de la alta sociedad 55 , cuya difusión en Alfar era exponente de la disparidad de criterios estéticos presentes en Alfar la revista.

Sobre Elena Olmos escribió en Alfar Julio J. Casal, su director, un texto temprano publicado en el número 24, en diciembre de 1922, momento en que la revista todavía cedía mucho espacio a temas relacionados con los consulados socios de la asociación Casa América, y año también en que la artista, habitual en las exposiciones regionales de arte gallego, se había lanzado con cierto éxito a la Exposición Nacional de Bellas Artes con su obra La niña de las naranjas. El autor no hablaba de ello. Sus palabras, breves, pero muy elogiosas, se limitaban a comparar a la autora con los grandes pintores por su maestría técnica y de color, poniendo como ejemplo un Retrato que ilustraba la portada (fig. 7) y dos reproducciones de sus obras: Adela y Rosalía y Retrato de la Vizcondesa de Palazuelos, esta última a página completa. Para Casal eran: "cuadros de alta escuela. [...] Muchos consagrados, cuyo nombre hace tiempo, cabalga a la grupa de la fama, ya quisieran ser dueños del trazo vibrante y sintético que caracteriza a esta hermana de cisnes y de rosas" 56 .

La última artista presente en Alfar, la chilena Laura Rodig (Los Andes, 1901-Santiago, 1972), de quien habló Huberto Pérez de la Ossa en 1925, sí encaja a la perfección con la nueva orientación plástica de la revista, merced a la simplificación evidente de sus temas pictóricos y escultóricos. Representaba, sin embargo, un modelo de mujer mucho más moderno que las anteriores: independiente y segura de sí misma, declarada feminista y disidente de los roles femeninos patriarcales del matrimonio y la maternidad, debido a su condición sexual y a su relación sentimental con Gabriela Mistral57, a quien conoció en 1916 cuando la escritora y maestra daba clases en el Liceo de los Andes, y sería por un tiempo su protectora, favoreciéndole un puesto de profesora de dibujo y escultura en el Liceo de Niñas de Punta Arenas ${ }^{58}$.

Rodig se había formado en la Academia de Bellas Artes de Santiago en la época en que fue director Fernando Álvarez Sotomayor. Su recha- zo a las enseñanzas academicistas de Virginio Arias le había costado una expulsión, en cuya readmisión intercedió el pintor españols9. Recibió después una beca que la llevó a París en 1928. La temática indigenista y el carácter social de su obra procedían de su viaje a México, donde se desplazó junto a Mistral, en las misiones educacionales de José Vasconcelos como misionera de la cultura indígena, en 1922. Allí conoció de primera mano el movimiento muralista, que difundió después en Chile, Estados Unidos, Uruguay y varios puntos de Europa, y fue lo más aplaudido por la crítica española tras su exposición, junto a José María Terry, en el Salón Nancy de Madrid en diciembre de 1924.

Gabriela Mistral y Laura Rodig residieron en España entre los últimos meses de 1924 y los primeros de 1925. Mientras la escritora y colaboradora de Alfar era homenajeada por el Pen Club de Madrid en el Lhardy50, Rodig promocionaba su obra en la capital ${ }^{61}$, donde la Junta de Museos adquirió su escultura India mexicana (fig. 8), un vaciado en escayola patinada que hoy conserva el MNCARS 62. Después llegarían a Coruña, invitadas por Julio J. Casal, y desde allí retornarían a Chile en febrero de 1925. El texto sobre la artista se publicó en Alfar un mes más tarde. Humberto Pérez de la Ossa lo tituló: "Una emoción de México en Madrid: Laura Rodig" 63 e iba ilustrado por ocho obras de la autora, en su mayoría apuntes de mercados, junto a las esculturas: Maternidad, Mujer triste e India mexicana, y un retrato de José Vasconcelos. El crítico destacó el exotismo de la temática, traída a Europa sin pasar por París, como Gaugin. Valoraba su honradez y frescura en el tratamiento de sus indios mexicanos, realizados desde el amor sincero y piadoso a la triste condición de esos pueblos. Y le parecían modernas, en consonancia con la nueva orientación estética de la revista, su frescura juvenil y la ausencia del amaneramiento propio del academicismo y los vanguardistas, empeñados en ser nuevos en todo. En sus propias palabras:

Con unos cuantos trazos de tizas de colores. Muy sintéticos [...] recogidos de prisa en sus viajes, esta chilena, poseída por el fervor del sol de México, [...] nos ha dicho de la Nueva España lo que nadie nos había sabido decir. Con una intuición muy clara y 
una gran precisión de línea y de ritmo, los apuntes de Laura Rodig son de una enorme fuerza sugestiva.

Otros textos sobre Rodig escritos en la misma época, incidieron también en su modernidad contenida, coincidente con la corriente novoclasicista y con las otras escultoras de la Sociedad de Artistas Ibéricos: Eva Aggerholm o Margarita Sans Jordi. La propia Gabriela Mistral la comparó con Rodin, con Donatello y los maestros clásicos, por llevar en sí "el anhelo de la delicadeza y de la fuerza a la vez, cosas sólo en apariencia contradictorias; una delicadeza suave y firme y un vigor sin exageraciones grotescas, el vigor tranquilo de los antiguos" ${ }^{64}$-escribía. Mistral decía también de ella que tenía el sentido de la "divinidad del Arte", que apreciaba la "belleza pequeña y la grande". Y admiraba su culto de los maestros y cómo entrelazaba a Rodin y a Mestróvic - "el uno todavía con Grecia en su frente y el otro con la visión enloquecida del alma contemporánea" - con su propio credo artístico e impresiones personales de mujer joven. Un texto escrito por Margarita Nelken en la revista Blanco y Negro recalcaba lo mismo: "es muy moderna -con las últimas adquisiciones simplificadoras de la estatuaria-, y muy antigua: con el estilización milenaria dictada por la raza misma" 65 . Nelken escribía sobre ella cinco años después de su exposición en Nancy, en 1929. Ese año, la chilena recibía una medalla en la Exposición Iberoamericana de Sevilla. Desde su Chile natal, y como una de las figuras centrales del Movimiento Pro Emancipación de las Mujeres de Chile, exhortó a sus compatriotas a solidarizarse con las españolas en la Guerra Civil y participó activamente en las campañas de ayuda a la República ${ }^{66}$, defendiendo a Dolores Ibárruri "La pasionaria", en un texto publicado en la página 4 del periódico La Hora, el 19 de julio de 193767.

La edición coruñesa de la revista Alfar no aportó evidencias femeninas representativas de la vía suprarreal planteada desde la SAI. Aunque Alfar se hizo eco del surrealismo publicando el manifiesto parisino pocos meses después de su aparición, y sendos artículos de Picón y Bretón llamados respectivamente "La revolución superrealista" (1925) y el "Texto super-realista" (1926), las mujeres artistas que manifestaron cierta cercanía al nuevo credo, como Ángeles Santos o Maruja Mallo, despuntaron a partir de 1928, fecha en que la revista había dejado de editarse en España antes de reaparecer en Uruguay.

\section{Recepción crítica del arte femenino y ba- lance final}

La vanguardia y la tradición convivieron también en la crítica a la mujer artista planteada desde Alfar. Fue novedosa e inusual la puesta en valor del arte femenino, pero se hizo reproduciendo los prejuicios sexistas corrientes en la crítica de arte española de la época, que han sido analizados por Rodrigo Villena, García Maldonado o P. Muñoz ${ }^{68}$.

En primer lugar, debe aclararse que la paridad entre hombres y mujeres en el ultraísmo plástico no concordó con la imagen de lo femenino lanzada desde el grupo. Lo que más llama la atención es que en una época en que las nuevas generaciones femeninas estaban luchando por sus derechos en los incipientes movimientos feministas; demostrando sus habilidades en casi todas las esferas de la actividad social y laboral tras la ocupación de puestos de trabajo masculinos durante la Primera Guerra Mundial; y en definitiva, iniciando su propia revolución en el sistema patriarcal, la llamada al progreso en los manifiestos ultraicos se hiciera sin contar con ellas ni reconocer su fortaleza. Por el contrario, los manifiestos ultraístas se dirigían expresamente a los hombres, utilizando un lenguaje intencionadamente machista que relacionaba progreso, juventud, fortaleza y poder, con masculinidad. En ellos se describía a los poetas como hombres "jóvenes y fuertes" 69 , "púgiles"70, "artistas que tienen músculos"71, "los fuertes, los puros, los selectos"72, asociando la conquista de la modernidad con una conquista amorosa a la que, según Guillermo de Torre, habría que ir "firmemente erectos como antenas"73, para vencer -en palabras de Isaac del Vando Villar- "el himen del futuro" 74; por citar sólo algunas de las metáforas sexuales de dominación hombre-mujer presentes en proclamas, poemas y boutades.

No menos contradicciones hallamos en el concepto de la mujer emitido por los jóvenes -y menos jóvenes- escritores del Ultra, que no teniendo como punto central de sus ataques el sentimentalismo y el amor romántico como sí ocurriera en el Futurismo italiano, mantuvieron a la mujer en 
su antiguo rol de musa, lavando su cara con imágenes modernas. Siguiendo los consejos de Jorge Luis Borges, de Isaac del Vando, de Guillermo de Torre y de Cansinos Assens, los poetas ultraístas huyeron de las rancias imágenes mitológicas y transformaron a las faunesas novecentistas en simples "hembras lúbricas"75; a las "princesitas de los bucles de oro"76 en "aviadoras" 77; o a Galatea en "la cowgirl del Far-West que practica todos los deportes, viste falda pantalón y maneja, como un falo portátil el revólver norteamericano"78; renegando en cambio de la mujer emancipada. Así se explicaba el tema en Cervantes, la revista en que se leyeron sus primeros manifiestos:

[...] más obtendrá la mujer siendo objeto de devoción de los hombres, que si, desviándose de su natural camino, trata de erigirse en adversario y competidor; porque entonces no será la belleza la que admiraremos, será la competencia lo que consideraremos, y toda la poesía que alrededor de la mujer pusimos, se trocará en vulgaridad ${ }^{79}$.

La musa ultraísta tampoco era la mujer corriente, la española de estar por casa, que el orientador teórico del grupo ${ }^{80}$, Rafael Cansinos Assens, caracterizó en la "Elegía del Hombre Crucificado" 81 , publicada en la misma revista revista, con los siguientes atributos nefastos: su vacuidad espiritual debida a sus "pensamientos pueriles"; su vida rutinaria y poco interesante; su inclinación natural a centrarse en sí misma; su actitud tradicionalista, sedentaria y apacible; y su tendencia a la exageración. En contraposición a este modelo femenino, Cansinos Asens describía al hombre como un ser rico espiritualmente pero incomprendido; que vivía el drama de soportar en silencio el peso de su "maravilloso pensamiento", al que la puerilidad femenina no alcanzaba e intimidaba; y el drama de tener como misión la profundidad de pensamientos osados, viéndose obligado a apurar el vaso del destino en todos los ámbitos. La única dignidad de la mujer era ser madre y por ello, el hombre debía tratarla bien y educarla: "Hacedla buena madre y habréis hallado su oficio", escribía Enrique Llavero en Grecia en 1919, añadiendo que "desde su gineceo, [la mujer] será un día legisladora: cuando de cada uno de sus hijos, sepa hacer un hombre" ${ }^{82}$.

A estas generalidades sobre la mujer, propias del conservadurismo de la vanguardia intelectual masculina, deben añadirse los prejuicios específicos sobre la creatividad femenina, que interfirieron también en las críticas a las escritoras y artistas divulgadas en Alfar. Casi todos coincidían en que la mujer, por imperativo biológico y debido a sus obligaciones maternales, había forjado un carácter y unas habilidades diferentes a las del hombre, que definieron en las revistas culturales del momento científicos e intelectuales como: Georges Simmel, Carl Jung, Gregorio Marañón, Edmundo González Blanco, Roberto Novoa Santos, etc. Éste último, autor de un conocido ensayo sobre la inferioridad femenina llamado La indigencia espiritual del sexo femenino (1908), donde decía que las mujeres originales eran casos patológicos de desviación de su sexo ${ }^{83}$, también colaboraba en Alfar. La aplicación de dichos prejuicios al terreno artístico había llevado a interiorizar la idea de un arte femenino y masculino diferentes, donde el hombre dominaba la ejecución técnica y la imaginación creadora, y la mujer compensaba sus carencias con su innata sensibilidad y delicadeza. En otras palabras: las obras femeninas eran menos correctas y audaces en el dibujo, en el color o en la elección del tema, pero tenían gracia, dulzura, ingenuidad, encanto, frescura, y una intuición natural que hacía olvidar a los críticos el esfuerzo personal, los años de estudio y las dificultades sociales y trabas morales por las que pasaban las artistas. El único mérito de las autoras, tratadas como casos excepcionales entre la mediocridad femenina, no era otro que el de poner la dosis justa de sus atributos femeniles, para no caer por exceso en la sensiblería -el mayor pecado atribuido a las mujeres artistas-y por defecto, en una exagerada virilización.

Algunos ejemplos extraídos de Alfar que ilustran estos preconceptos sexistas, son:

-[F. Martínez Mora sobre las mujeres gallegas Concepción Arenal, Rosalía de Castro y Pardo Bazán]: "[...] el apego al terruño, el espíritu conservador de lo tradicional, lo eterno, lo intrínseco [...]: el hondo sentimentalismo, y la extraordinaria viveza intelectual, la instintiva bondad [...], caracterizan el alma de nuestras mujeres" $"$.

-[Humberto Pérez de la Ossa sobre Concha Espina]: "Hay dos maneras de sentir el paisaje: una de enamorado gozador que se adueña de él, que lo 
posee; otra de modo inverso: el que se deja poseer del paisaje. Parece este el modo más femenino" ${ }^{185}$.

-[Guillermo de Torre sobre las poetisas argentinas Norah Lange, María Clemencia López Pombo y Helena M. Murguiondo]: "[son] muy líricas y muy femeninas", "[en las tres] la cualidad femínea, neta y desenfadadamente femenina, hasta los límites más audaces de la sinceridad erótica, es la que más resplandece" ${ }^{\prime 86}$.

-[Luis Antonio de Vega sobre la escritora peruana Angélica Palma]: "bella escritora limeña", "alma maravillosamente femenina", "graciosa alma tierna", "delicadas prosas", "delicada narración donde las palabras precisas aparecen con dulzura tranquila"87.

-[Guillermo de Torre sobre Norah Borges]: "musa de la xilografia"s8, "...iridiscente sensibilidad femínea. Que aspira a conservar sin mixtificaciones cerebrales", "ingenuidad temperamental"89.

-[Manuel Abril]: "Norah Borges sabe muy bien, como mujer, lo de obedecer a las leyes jugando (la feminidad consiste en eso: en hacer del juego una técnica para mejor cumplimiento del Designio)"

-[Humberto Pérez de la Ossa sobre Laura Rodig]: "joven y delicada", pero capaz de hacer una "obra recia, fuerte, por el camino de la gracia". [...] "Nada de frivolidad, nada de afeminamiento en su labor. Laura Rodig siente la escultura con toda la dignidad de la fuerza interna, con el grávido reposo de las masas potentes. La materia y el volumen tienen su verdadero sentido siempre; por eso los que no conciben la fuerza femenina (el poder de las mujeres fuertes, muy distinto de la virilidad), ante las estatuas de Laura Rodig creen hallarse ante la obra de un hombre ${ }^{91}$.

Con todo, más allá de esta visión conservadora y de los prejuicios sobre la mujer y la artista, la atención que recibió la creación femenina en Alfar fue muy superior a la que obtuvo en otras revistas de la vanguardia española. Empezando por la también gallega Ronsel, publicación efímera y pretendidamente ecléctica dirigida por Evaristo Correa Calderón y el caricaturista Álvaro Cebreiro, en ella solo se pudo leer el nombre de Norah Borges, de quien se publicó en el número 4 un grabado en madera llamado Fiesta flamenca, ejemplo de ultraísmo y dinamismo poco frecuente ya por esos años ${ }^{92}$. La revista, a caballo también entre la vanguardia y el novoclasicismo, tanto en las colaboraciones literarias como en las plásticas, donde convivían obras de Julio Antonio y Jesús Corredoyra con las de Cebreiro, Barradas, Benjamín Palencia, o Alberto Sánchez ${ }^{93}$, parecía anunciarse como una revista masculina, dirigida específicamente a los hombres, según se deduce de la siguiente llamada a los lectores publicada por Sanin Cano en el número 5: "Adelante, hombres de "Ronsel", que vuestro bello gesto sirva algún día para que los jóvenes se desembarquen de la tutela senil y tengan aún el coraje de no volver hacia atrás los ojos cuando las pupilas empiezan a enturbiarse mirando hacia delante" ${ }_{94}$.

La ausencia de nombres femeninos en la mayoría de publicaciones de la vanguardia que antecedieron o se editaron paralelamente a Alfar, incluso en las que tenían secciones artísticas, reafirman la singularidad de Alfar en este aspecto. Por ejemplo, en Cervantes no se escribió sobre ninguna artista, más allá de nombrar a algunas entre los artistas presentes en la Nacional de 1917 y en la Exposición de Bellos Oficios de 1918. Lo mismo en Cosmópolis, donde solo Norah Borges, citada dentro de un artículo más amplio sobre el renacimiento xilográfico, tuvo un pequeño espacio de crítica. En Grecia, Norah Borges ilustró algunas de sus páginas y se le dedicaron algunos poemas, como también a Sonia Delaunay, siendo los únicos casos. En Ultra, junto a la reproducción de algunos grabados de Norah Borges y una escultura de Eva Aggerholm, solo se escribió sobre la joven pintora Ruth Velasco, compartiendo espacio con el también pintor Santiago Vera. Nada en las revistas Reflector, Tableros y Horizontes, salvo algún grabado de Norah Borges. Nada en Vértices y en Tobogán, ni en las revistas de Juan Ramón: Índice, Si (Boletín Bello Español) y Ley.

Por lo tanto, el caso de la revista Alfar, con sus seis mujeres artistas, las colaboraciones de escritoras y los textos críticos sobre algunas de ellas, los trabajos musicales de y sobre Carmen Barradas, y un texto en dos entregas, en septiembre y noviembre de 1924, en el que Adolfo Salazar describía, desde la comprensión de los intereses de ambos, los vaivenes del matrimonio de Minna Wagner con el genio apasionado, fue una excepción respecto a las revistas homólogas, incluidas las pertenecientes a la Generación 27, algunas de 
las cuales ni siquiera tuvieron colaboraciones femeninas literarias, caso de Litoral, La Rosa de los Vientos, Carmen y Gallo. Entre las publicaciones del 27, la que más seguimiento hizo de la creación femenina fue La Gaceta Literaria”, dado su mayor alcance cultural e interés por las cuestiones artísticas, y evidentemente, debido a su mayor recorrido temporal entre 1927 y 1932. La publicación dirigida por Giménez Caballero, además de incluir comentarios breves sobre una docena de artistas al hilo de la crónica de exposiciones que sostenían Juan de la Encina, Rafael Marquina y Lafuente Ferrari, narró con varios trabajos el giro definitivo de Norah Borges hacia el clasicismo y el despuntar de dos nuevas artistas que nacieron al amparo de la generación: Ángeles Santos, vallisoletana, y Maruja Mallo, gallega. Esta última fue ilustradora de Alfar en su etapa de Montevideo, y se escribieron sobre ella varios textos antes y después de su exilio americano, lo que demuestra que se siguió hablando de mujeres artistas en la Alfar uruguaya, aunque este constituye ya un capitulo diferente en lo geográfico, en lo temporal y en la propia historia de las mujeres artistas. En los años treinta, Maruja Mallo, Ángeles Santos y otras pintoras de la nueva figuración como Marisa Roësset o Rosario de Velasco, por citar solo a las mejor recibidas por la crítica, representaron en España a una nueva generación de mujeres artistas profesionales, salidas muchas de ellas de las Academias de Bellas Artes, que sin estar necesariamente protegidas e integradas en el arte y la cultura por sus familiares varones, como sí ocurrió con las artistas de Alfar, contribuyeron a romper con la idea negativa y estereotipada que se tenía del arte femenino. 
NOTAS

J. Brihuega, Las Vanguardias Artísticas en España. 1910-1931. Manifiestos, proclamas, panfletos y textos doctrinales, Cátedra, Madrid, 1979, pp. 155-156.

2 Los fondos de la revista están digitalizados por la Universidad de la República de Uruguay. Vid: http://anaforas.fic.edu.uy/jspui/handle/123456789/4668, para los números correspondientes a Revista Casa América-Galicia, y http://anaforas.fic.edu.uy/ jspui/handle/123456789/5562, para los correspondientes a Alfar.

3 C.A. Molina, La revista "Alfar» y la prensa literaria de la época (19201930), 5. Vol., Nos, La Coruña, 1984.

4 V. G. de la Concha, "'Alfar': Historia de dos revistas. 1920-1927", Cuadernos Hispanoamericanos, $n^{\circ} 255$, 1971, pp. 500-535.

5 G. Videla, El ultraísmo. Estudios sobre movimientos poéticos de vanguardia en España, Gredos, Madrid, 1971.

6 J.M. Rozas, El 27 como generación, Sur Ediciones, Santander, 1978, p. 73.

7 El antiguo Boletín de Casa América-Galicia, se llamó después: América Galicia. Revista Comercial ilustrada Iberoamericana y Revista Casa América Galicia (números 21-32). El sobrenombre Alfar se lo otorgó Julio J. Casal en el número 33. Vid.: C.A. Molina, "Presentación", en La revista «Alfar»..., op. cit. $s / p$.

8 V.G. de la Concha, "Alfar...", op. cit., pp. 505-506 y 531-533.

9 M. Martínez Pérsico, La gloria y la memoria. El Ultraísmo iberoamericano 'suivant les traces' de Cansinos Assens, Editer BoD, 2012, p. 143.

10 Publicaron escritos sobre arte y artistas en Alfar: Manuel Abril, Rafael Alberti. Julio J. Casal, Juan Chabás, Gonzalo Deza, Juan de la Encina, Adolphe Falgairolle, Ángel Ferrant, Juan Gris, Jaime Ibarra, Demetrio Korsi, Vizconde de Lazcano Tegui. Francisco Miguel, Marján Paszkiewicz, Alfonso Mosquera, Humberto Pérez de la Ossa, Maurice Raynal, Adolfo Salazar, Albert Shenneberger, Jules Supervielle, J. Su- bías, Ramón María Tenreiro, Guillermo de Torre y Cesar Vallejo.

11 G. de Torre, "Tres nuevas poetisas argentinas", Revista de Casa de América-Galicia, n² 29, mayo de 1923 , p. 274.

12 E. Carmona, "Tipografías desdobladas. El arte nuevo y las revistas de creación entre el novecientos y la vanguardia, 1918-1936" en Arte moderno y revistas españolas. 1898-1936 (cat. exp.), Museo Nacional Reina Sofía, Madrid, 1997, pp. 72-73.

$$
\begin{aligned}
& 13 \text { Ibid., p. } 73 . \\
& 14 \text { Ibidem. }
\end{aligned}
$$

15 J. M. Bonet, "La novela y la pintura de Francisco Miguel", $A B C, 20$ de noviembre de 1999, p. 46.

16 E. Carmona, "Bores ultraísta, clásico, nuevo" en Francisco Bores. El ultraísmo y el ambiente literario madrileño 1921-1925 (cat. exp.), Publicaciones de la Residencia de Estudiantes, Madrid, 1999, p. 17.

17 G. de Torre, "Literaturas novísimas. El movimiento ultraísta español", Cosmópolis, $n^{\circ} 2$, noviembre 1920, $p$. 482.

18 G. de Torre, "Dos pintores de Vanguardia: Ruth Velázquez y Santiago Vera", Ultra, n 12, 30 de mayo de 1921, p. 4.

19 G. de Torre, Literaturas europeas de vanguardia, op. cit., p. 54.

20 G. de Torre, "Dos pintores de Vanguardia: Ruth Velázquez y Santiago Vera", op. cit., p. 4.

${ }^{21}$ G. de Torre, "Literaturas novísimas...", op. cit. p. 482.

22 J. G. del Valle y G. de la Vega, "Una compositora uruguaya: Carmen Barradas", Casa América Galicia, n²5, enero de 1923.

${ }^{23}$ M. Molina, "El artista del 'Mono Azul': sonidos de la era industrial" en Del mono azul al cuello blanco: Transformación social y práctica artística en la era postindustrial (cat. exp.), Consellería de Cultura de la Generalitat Valenciana, Valencia, 2003, p. 10.

24 G. Gómez de la Serna, Norah Borges, Losada, Buenos Aires, 1946, pp. 6-7.
${ }^{25}$ A. del Valle Hernández, Adriano del Valle, mi padre, Renacimiento, Sevilla, 2006, p. 50.

26 R. Quance, "Espacios masculinos/femeninos. Norah Borges en las vanguardias", Dossiers Feministes, $\mathrm{n}^{\circ}$ 20, 2007, pp. 234-235.

27 J. M. Bonet, "Hora y media con Norah Borges", Renacimiento, $\mathrm{n}^{\circ} 8$, 1992, pp. 5-6.

28 I. del Vando, "Una pintora ultraísta", Grecia, n 38, 20 de enero de 1920, p. 6.

29 G. de Torre, "Interpretación y sugerencias. El renacimiento xilográfico. Tres grabadores ultraístas", Cosmópolis, $n^{\circ} 44$, agosto de 1922, pp. 333-336.

${ }^{30} \mathrm{G}$. de Torre, "El arte candoroso y torturado de Norah Borges", Grecia, n 44, 15 de junio de 1920, p. 6.

31 Ibid., p. 7.

32 G. de Torre, "Retrato" (de Norah Borges), Alfar (ed. facsímil), n²7, marzo de 1923, p. 201.

33 R. Quance, "Espacios masculinos/femeninos. Norah Borges...", op. cit., p. 240.

34 Ibid., pp. 233 y 245

35 G. de Torre, "Visita del 'Interviewer ignotus' al autor de 'Hélices'", Revista de Casa de América-Galicia (ed. facsímil), n²8, abril 1923, pp. 236238.

${ }^{36}$ M. Abril, "La dama del ajedrez", Alfar (ed. facsímil), $n^{\circ} 36$, enero de 1924, p. 196.

37 "Casa Sonia" fue una firma registrada; no un local abierto para la exposición y venta de sus productos, que la artista mostraba en su propio domicilio o en lugares como el Salón Matheu de Madrid. M. Ruiz del Árbol, "El arte total y Casa Sonia" en Sonia Delaunay. Arte, diseño y moda (cat. exp.), Museo Thyssen, Madrid, 2017, pp. 87-107.

38 S. Cendán, "Sonia Delaunay\&Alfar. Paisajes de una relación singular", Abrente, $\mathrm{n}^{\circ}$ 42-43, 2010-2011, pp. 401-415.

39 I. del Vando, "Sonia Delaunay", Grecia, $n^{\circ} 48$, 1 de septiembre de 1920, p. 3.

40 G. de Torre, "Madrid-París. Álbum de Retratos. Mis amigos y yo", 
Grecia, n 48, 1 de septiembre de 1920, pp. 11-12.

41 R. Cansinos-Assens, El movimiento V.P. (ed. facsímil), Ediciones Peralta/Libros Hiperión, Pamplona, 1978. p. 165.

42 G. de Torre, "El arte decorativo de Sonia Delaunay-Terk", Alfar (ed. facsímil), n³5, diciembre de 1923, p. 160.

43 Ibídem.

${ }^{44}$ E. de Torre Villar, Ilustradores de libros. Guion bibliográfico, Universidad Nacional Autónoma de México, 1999, pp. 86-96.

45 R. Gómez de la Serna, "Riverismo", Sur, añol, otoño de 1931, p. 65.

46 E. Carmona, "Tipografías desdobladas...", op. cit. p. 73.

47 Ibíd. p. 74.

48 El Catálogo Oficial de la Exposición Nacional de Bellas Artes de 1924 (Matheu Artes Gráficas, Madrid, 1924) escribe que Aida Uribe era de Guatemala, discípula Ángel Laroque, y que vivía en la calle Sacramento 19, de Zarauz. En cambio, el Catálogo del cuarto Salón de Otoño. Fundado por la Asociación de Pintores y Escultores. Madrid, octubre 1923, la sitúa en la calle Sacramento 10 , de Madrid.

49 "Salón de Artistas Ibéricos: La Exposición - De "El Sol", Madrid", en Alfar, $n^{\circ}$ 51, julio de 1925, p. 4.

50 J. Pérez Segura, La sociedad de artistas ibéricos (1920-1936), tesis doctoral, vol. 1, Universidad Complutense, Madrid, 1997, p. 174. Disponible en: http://eprints.ucm.es/2478/1/T22384. pdf.

51 F. Alcántara, "Los artistas ibéricos", El sol, 14 de julio de 1925, p. 2.

52 J. Francés, "La Exposición Nacional de Bellas Artes", El Año Artístico 1924, Mundo Latino, Madrid, 1925, p. 291.

53 A. Espina, "Paisajes de puertas adentro: Aída Uribe; María Luisa Pérez Herrero; Ricardo Baroja", La Gaceta Literaria, $\mathrm{n}^{\circ} 10,15$ de mayo de 1927, $\mathrm{p}$. 5.

54 F. Pereira Bueno, Mulleres pintoras na arte galega (segunda metade do século XIX e primeiro terzo do século $X X$ ). Unha historia de invisibilidade, Consello da Cultura Galega. Comisión de Igualdade, 2009, p. 15.
${ }^{55}$ F. Pereira Bueno, A presenza das mulleres pintoras na arte galega: 18581936, Edicios Do Castro, A Coruña, 2004, pp. 166-167.

56 Julio J. Casal, "Elena Olmos", Casa de América-Galicia (ed. facsímil), n²4, diciembre de 1922, pp. 104-105.

57 M. Vergara, Memorias de una mujer irreverente, Editorial Gabriela Mistral, Santiago de Chile, 1974, p. 342 y G. Cortés Aliaga, "Estéticas de la resistencia: Las artistas chilenas y la vanguardia femenina (1900-1936)", Artelogíe, $\mathrm{n}^{\circ} 5$, 2013, p. 24, ARTELOGIE [Consulta: 14/01/2016]. http://cral. in2p3.fr/artelogie/spip.php?article261

58 Y. Valdebenito Carrasco, "Laura Rodig Pizarro: un caso de estudio en la historiografía del arte chileno desde un enfoque de género", Anales de la Historia del Arte, $n^{\circ} 28,2018$, p. 227.

59 "Mujer y territorio. Laura Rodig y su vida artística en Magallanes". MUSEO REGIONAL DE MAGALLANES/ DIBAM [Consulta: 10/10/2017]. http:// www.museodemagallanes.cl/645/w3article-55352.html

60 A. Caballé, "Gabriela Mistral en Madrid", Anales de literatura hispanoamericana, $n^{\circ} 22,1993$, pp. 236-237.

61 Otras fuentes la sitúan también en el Museo de Arte Moderno de Madrid, dato erróneo, y en la Galería Arte Nuevo. G. Cortés Aliaga, "Estéticas de la resistencia: Las artistas chilenas...", op. cit., p. 24. G. Cortés Aliaga, Modernas. Historias de mujeres en el arte chileno (1900-1950), Origo Ediciones, Santiago de Chile, 2013, p. 180.

62 India mexicana, Museo Nacional Centro de Arte Reina Sofía. $N^{\circ}$ de Registro: AS00351.

${ }^{63}$ H. Pérez de la Ossa, "Una emoción de México en Madrid: Laura Rodig", Alfar, no 47, febrero de 1925, pp. 16-20.

${ }^{64}$ G. Mistral, Grandeza de los oficios, Editorial Andrés Bello, Santiago de Chile, 1979.

65 M. Nelken, "La explosión disciplinada: Laura Rodig", Blanco y Negro, n 1981, 29 de mayo de 1929, p. 94.

${ }^{66}$ M. Barchino (ed.), Chile y la guerra civil española. La voz de los intelectuales, Calambur, Madrid, 2013, s/p.
67 Véase un desarrollo más amplio de las implicaciones políticas y del feminismo activo de Laura Rodig en: Y. Valdebenito Carrasco, "Laura Rodig Pizarro...", op. cit., pp. 225-245.

68 Sobre la crítica a la mujer artista en el primer tercio del siglo $\mathrm{XX}$, véase: I. Rodrigo Villena, "Crítica de arte y polémicas de género en la España del primer tercio del siglo XX». En Actas del XVII Congrés Nacional d'Història de l'Art. CEHA, Atrio, Granada 2017, pp. 1242-1256; B. García Maldonado, "La mujer artista ante la crítica de arte (1910-1936)", AACA Digital. Revista de la Asociación Aragonesa de Críticos de Arte, $\mathrm{n}^{\circ}$ 17, 2011, s/p., AACA DIGITAL: [Consulta: 06/05/2017]. http://www.aacadigital.com/contenido. php? idindice=2; y P. Muñoz, "Las mujeres como creadoras en las artes plásticas según los textos de hombres y mujeres en la España de la primera mitad del siglo $X^{\prime \prime}$, Arenal, vol. 19, $n^{\circ} 2$, juliodiciembre de 2012, pp. 393-413. UGR [Consulta: 12/10/2017], http://www. ugr.es/ arenal/articulo.php?id=195.

69 I. del Vando, "El triunfo del ultraísmo", Grecia, n² 29, octubre de 1919, pp. 1-2.

${ }^{70} \mathrm{G}$. de Torre, "Manifiesto ultraísta vertical", Grecia, n 50, 1 de noviembre de 1920, s/p.

71 G. de Torre, "Del tema moderno como 'número de fuerza'", Mediodía, $n^{\circ}$ 8, 1927, pp. 12-13.

72 Boutade sin autoría incluida en Ultra, n 13, 10 de junio de 1921, p. 1.

${ }^{73}$ G. de Torre, "Manifiesto ultraísta vertical", op. cit., s/p.

74 I. del Vando, "Manifiesto ultraísta", Grecia, n²0, 30 de junio de 1919, p. 9.

75 J.L. Borges, "Al margen de la lírica moderna", Grecia, n 34, 31 de enero de 1920, p. 16 y ss.

76 I. del Vando, "El triunfo del ultraísmo", op. cit., pp. 1-2.

77 G. de Torre, "Manifiesto ultraísta vertical", op. cit., s/p.

78 R. Cansinos Assens, El movimiento V.P., op. cit., p. 14.

79 A. Ballesteros de Martos, "Artes plásticas. El suntuoso sensualismo de Federico Beltrán", Cervantes, agosto de 1919, pp. 83 y 87. 
${ }^{80}$ Guillermo de Torre reconoció la orientación teórica del Ultraísmo a Rafael Cansinos Assens, negándosela después. Véase sobre ello: López Cobo, "El ansia ultraísta de Guillermo de Torre", AnMal, vol. XXXI, n 1, 2008, pp. 61-77 (p. 68).

81 R. Cansinos Assens, "Elegía de los hombres crucificados", Cervantes, abril de 1919, pp. 1-13.

82 E. Llavero, "De la mujer", Grecia, n²9, 12 de octubre de 1919, p. 6 y E. Llavero: "De la mujer", Grecia, n 35, 10 de diciembre de 1919, p. 4.

83 R. Novoa Santos, La indigencia espiritual del sexo femenino (las pruebas anatómicas, fisiológicas y psicológicas de la pobreza mental de la mujer. Su explicación biológica), Valencia, 1908, p. 119.

${ }^{84}$ F. Martínez Mora, "La mujer gallega", Revista Casa América-Galicia, n 31, julio de 1923, pp. 13-15.
85 H. Pérez de la Ossa, "Concha Espina: El dolor en el arte", Alfar. n 38, marzo de 1924, p. 20.

${ }^{86}$ G. de Torre, "Tres nuevas poetisas argentinas", op. cit., p. 274.

87 L. A. de Vega, "Coloniaje Romántico", Revista Casa América-Galicia, $n^{\circ} 32$, septiembre de 1923, p. 38.

88 G. de Torre, "Visita del 'Interviewer ignotus' al autor de 'Hélices'", op. cit., p. 238.

89 G. de Torre, "Retrato" (de Norah Borges)", op. cit., p. 201.

${ }^{90}$ M. Abril, "La dama del ajedrez", op. cit., p. 196.

91 H. Pérez de la Ossa, "Una emoción de México en Madrid: Laura Rodig" op. cit., pp. 16-17.

92 M. V. Carballo, "El arte nuevo y las revistas de creación en Galicia (19181936). Ronsel (Lugo, 1924), una revista 'ecléctica' ", Abrente, n 40-41, 20092010, p. 316.

93 J. M. Bonet Correa, "'Ronsel' y el arte de vanguardia", en Ronsel. Revista de Literatura y arte. Número conmemorativo del cincuentenario de su publicación 1924-1974, Lugo, 15 de enero de 1975, p. 8.

94 B. Sanin Cano, "De Senectute", Ronsel. Revista de Arte, $\mathrm{n}^{\circ}$ 5, septiembre de 1924, p. 5. El subrayado en la palabra "hombre" no aparece en el texto original.

${ }_{95}$ Véase: I. Rodrigo Villena, "La Gaceta Literaria (1927-1931) y sus pintoras modernas". En XI Congreso virtual sobre Historia de las Mujeres. 15 al 31 de octubre de 1919. Comunicaciones, Asociación de Amigos del Archivo Histórico Diocesano, Jaén, 2019, pp. 645-668. REVISTA ÍNDICE://www.revistacodice. es/publi_virtuales/xi_congreso_mujeres/ comunicaciones/34_rodrigo_villena.pdf 


\section{REFERENCIAS}

Abril, Manuel. 1924. "La dama del ajedrez." Alfar 36 (Enero): 196.

Alcántara, Francisco. "Los artistas ibéricos", El Sol, Julio 14, 1925.

Ballesteros de Martos, Antonio. 1919. "Artes plásticas. El suntuoso sensualismo de Federico Beltrán." Cervantes, Agosto: 77-91.

Barchino, Matías, ed. 2013. Chile y la guerra civil española. La voz de los intelectuales. Madrid: Calambur.

Bonet, Juan Manuel. 1975. "'Ronsel' y el arte de vanguardia." Ronsel. Revista de Literatura y arte. Número conmemorativo del cincuentenario de su publicación 1924-1974 15 (Enero): 9-13.

Bonet, Juan Manuel. 1992. "Hora y media con Norah Borges." Renacimiento 8: 5-6.

Bonet, Juan Manuel. 1999. "La novela y la pintura de Francisco Miguel." $A B C$, Noviembre 20, 1999.

Borges, Jorge Luis. 1920. "Al margen de la lírica moderna." Grecia 34 (Enero 31): 16.

Brihuega, Jaime. 1979. Las Vanguardias Artísticas en España. 1910-1931. Manifiestos, proclamas, panfletos y textos doctrinales. Madrid: Cátedra.

Caballé, Anna. 1993. "Gabriela Mistral en Madrid." Anales de literatura hispanoamericana 22: 231-246.

Cansinos Assens, Rafael. 1919. "Elegía de los hombres crucificados." Cervantes (Abril): 3-13.

Cansinos-Assens, Rafael. 1978. El movimiento V.P. (ed. facsímil). Pamplona: Ediciones Peralta/Libros Hiperión.

Carballo, María Victoria. 2009-2010. “El arte nuevo y las revistas de creación en Galicia (1918-1936). Ronsel (Lugo, 1924), una revista 'ecléctica'." Abrente 40-41: 305-324.

Carmona, Eugenio. 1997. "Tipografías desdobladas. El arte nuevo y las revistas de creación entre el novecientos y la vanguardia, 1918-
1936." In Arte moderno y revistas españolas. 1898-1936, edited by Eugenio Carmona y Juan José Lahuerta, 63-102. Madrid: MNCARS.

Carmona, Eugenio. 1999. "Bores ultraísta, clásico, nuevo." In Francisco Bores. El ultraísmo y el ambiente literario madrileño 1921-1925 (cat. exp.), 11-23. Madrid: Publicaciones de la Residencia de Estudiantes.

Casal, Julio J. 1922. "Elena Olmos." Revista de Casa de América-Galicia 24 (Diciembre): 8-9.

Cendán, Susana. 2010-2011. "Sonia Delaunay\&Alfar. Paisajes de una relación singular." Abrente 42-43: 401-416.

Concha, Victor G. de la. 1971. "Alfar: Historia de dos revistas. 1920-1927." Cuadernos Hispanoamericanos 255 (Marzo): 500-535.

Cortés Aliaga, Gloria. 2013. "Estéticas de la resistencia: Las artistas chilenas y la vanguardia femenina (1900-1936)." Artelogíe 5: 1-25. Accessed Jaunary 14, 2016. http://cral.in2p3. fr/artelogie/spip.php?article261.

Cortés Aliaga, Gloria. 2013. Modernas. Historias de mujeres en el arte chileno (1900-1950). Santiago de Chile: Origo Ediciones.

Espina, Antonio. 1927. "Paisajes de puertas adentro: Aída Uribe; María Luisa Pérez Herrero; Ricardo Baroja." La Gaceta Literaria 10 (Mayo 15): 5.

Francés, José. 1925. "La Exposición Nacional de Bellas Artes." In El Año Artístico 1924, 273292. Madrid: Mundo Latino.

García Maldonado, Begoña. 2011. "La mujer artista ante la crítica de arte (1910-1936)." AACA Digital. Revista de la Asociación Aragonesa de Críticos de Arte 17. Accessed May 6, 2017. http://www.aacadigital.com/contenido. php? idindice $=2$.

Gómez de la Serna, Ramón. 1931. "Riverismo." Sur I (Otoño): 59-85.

Gómez de la Serna, Ramón. 1946. Norah Borges. Buenos Aires: Losada.

Llavero, Enrique. 1919. "De la mujer." Grecia 29 (Octubre 12): 6. 
Llavero, Enrique. 1919. "De la mujer." Grecia 35 (Diciembre 10): 4.

López Cobo, Azucena. 2008. “El ansia ultraísta de Guillermo de Torre." AnMal 31 (1): 61-77.

Martínez Mora, F. 1923. "La mujer gallega." Revista de Casa América-Galicia 31 (Julio): 13-15.

Martínez Pérsico, Marisa. 2012. La gloria y la memoria. El Ultraísmo iberoamericano 'suivant les traces' de Cansinos Assens. París: BoD.

Mistral, Gabriela. 1979. Grandeza de los oficios. Santiago de Chile: Editorial Andrés Bello.

Molina, Cesar Antonio. 1984. La revista «Alfar» y la prensa literaria de la época (1920-1930). La Coruña: Nos.

Molina, Miguel. 2003. "El artista del 'Mono Azul': sonidos de la era industrial." In Del mono azul al cuello blanco: Transformación social y práctica artística en la era postindustrial (cat. exp.), 1-10. Valencia: Consellería de Cultura de la Generalitat Valenciana.

Muñoz, Pilar. 2012. "Las mujeres como creadoras en las artes plásticas según los textos de hombres y mujeres en la España de la primera mitad del siglo XX." Arenal 19 (2): 393-413. Accessed October 12, 2017. http://www.ugr. es/ arenal/articulo. php?id=195.

Museo Nacional de Bellas Artes de Santiago de Chile. "Artistas Plásticos Chilenos: Laura Rodig." Accessed September 7, 2017. http:// www.artistasvisualeschilenos.cl/658/w3-article-40178.html.

Museo Regional de Magallanes/DIBAM. "Mujer y territorio. Laura Rodig y su vida artística en Magallanes." Accessed October 10, 2017. http://www.museodemagallanes.cl/645/w3article-55352.html.

Nelken, Margarita. 1929. “La explosión disciplinada: Laura Rodig." Blanco y Negro 1981 (Mayo 5): 94.

Novoa Santos, Roberto. 1908. La indigencia espiritual del sexo femenino (las pruebas anatómicas, fisiológicas y psicológicas de la pobreza mental de la mujer. Su explicación biológica). Valencia: F. Sempere y Compañía.
Pereira Bueno, Fernando. 2004. A presenza das mulleres pintoras na arte galega: 1858-1936. A Coruña: Edicios Do Castro.

Pereira Bueno, Fernando. 2009. Mulleres pintoras na arte galega (segunda metade do século XIX e primeiro terzo do século XX). Unha historia de invisibilidade. A Coruña: Consello da Cultura Galega.

Pérez de la Ossa, Humberto. 1924. "Concha Espina: El dolor en el arte." Alfar 38 (Marzo): 20.

Pérez de la Ossa, Humberto. 1925. "Una emoción de México en Madrid: Laura Rodig." Alfar 47 (Febrero): 16-20.

Pérez Segura, Javier. 1997. "La sociedad de artistas ibéricos (1920-1936)." PhD diss., Universidad Complutense de Madrid.

Pradó Nieto, Bernat. 2014. "Historia intelectual de la revista Alfar (1920-1927)." PhD diss., Universidad de Zaragoza.

Quance, Roberta Ann. 2007. “Espacios masculinos/femeninos. Norah Borges en las vanguardias." Dossiers Feministes 10: 233-248.

Rodrigo Villena, Isabel. 2017. "Crítica de arte y polémicas de género en la España del primer tercio del siglo XX." In Actas del XVII Congrés Nacional d'Història de l'Art. CEHA, 12421256. Granada: Atrio.

Rodrigo Villena, Isabel. 2019. "La Gaceta Literaria (1927-1931) y sus pintoras modernas." In XI Congreso virtual sobre Historia de las Mujeres. 15 al 31 de octubre de 1919. Comunicaciones, 645-668. Asociación de Amigos del Archivo Histórico Diocesano: Jaén. https://www.revistacodice.es/publi_virtuales/xi_congreso_mujeres/comunicaciones/34_rodrigo_villena.pdf

Rozas, Juan Manuel. 1978. El 27 como generación. Santander: Sur Ediciones.

Ruiz del Árbol, Marta. 2017. “El arte total y Casa Sonia." In Sonia Delaunay. Arte, diseño y moda (cat. exp.) 87-107. Madrid: Museo Thyssen.

"Salón de Artistas Ibéricos. Manifiesto (De El Sol. Madrid)." Alfar 51 (Julio): 2-5.

Sanín Cano, Baldomero. 1924. "De Senectute." Ronsel. Revista de Arte 5 (Septiembre): 3-5. 
Torre, Guillermo de. 1920 "Manifiesto ultraísta vertical." Grecia 50 (Noviembre 1): s/p.

Torre, Guillermo de. 1920. "El arte candoroso y torturado de Norah Borges." Grecia 44 (Julio 15): 6-7.

Torre, Guillermo de. 1920. "Literaturas novísimas. El movimiento ultraísta español. I" Cosmópolis 2 (Noviembre): 284-296.

Torre, Guillermo de. 1920. "Madrid-París. Álbum de Retratos. Mis amigos y yo." Grecia 48 (Septiembre 1): 11-12.

Torre, Guillermo de. 1921. "Dos pintores de Vanguardia: Ruth Velázquez y Santiago Vera." UItra 12 (Mayo 30): 4

Torre, Guillermo de. 1922. "Interpretación y sugerencias. El renacimiento xilográfico. Tres grabadores ultraístas." Cosmópolis 44 (Agosto): 333-336.

Torre, Guillermo de. 1923. "El arte decorativo de Sonia Delaunay-Terk." Alfar 35 (Diciembre): 18-19.

Torre, Guillermo de. 1923. "Retrato (de Norah Borges)." Alfar 27 (Marzo): 201.

Torre, Guillermo de. 1923. "Tres nuevas poetisas argentinas." Revista de Casa América-Galicia 29 (Mayo): 8.

Torre, Guillermo de. 1923. "Visita del 'Interviewer ignotus' al autor de 'Hélices'. ." Revista de Casa América-Galicia 28 (Abril): 6-8.

Torre, Guillermo de. 1925. Literaturas europeas de vanguardia. Madrid: Rafael Caro Editor.

Torre, Guillermo de. 1927. "Del tema moderno como 'número de fuerza'. "Mediodía 8: 12-13.
Torre Villar, Ernesto de. 1999. Ilustradores de libros. Guion bibliográfico. México: Universidad Nacional Autónoma.

Valdebenito Carrasco, Yocelyn. 2018. "Laura Rodig Pizarro: un caso de estudio en la historiografía del arte chileno desde un enfoque de género." Anales de la Historia del Arte 28: 225-245. https://doi.org/10.5209/anha.61613

Valle Hernández, Adrián del. 2006. Adriano del Valle, mi padre. Sevilla: Renacimiento.

Valle, Juan G. del. 1923. "Una compositora uruguaya: Carmen Barradas." Revista de Casa América-Galicia 25 (Enero): 7.

Vando, Isaac del. 1919. "El triunfo del ultraísmo." Grecia 29 (Octubre 12): 1-2.

Vando, Isaac del. 1919. "Manifiesto ultraísta." Grecia 20 (Junio 30): 9.

Vando, Isaac del. 1920. "Sonia Delaunay." Grecia 48 (Septiembre 1): 3.

Vando, Isaac del. 1920. "Una pintora ultraísta." Grecia 38 (Enero 20): 12.

Vega, Luis Antonio de. 1923. "Coloniaje Romántico." Revista de Casa América-Galicia 32 (Septiembre): 38.

Vergara, Marta. 1974. Memorias de una mujer irreverente. Santiago de Chile: Editorial Gabriela Mistral.

Videla, Gloria. 1971. El ultraísmo. Estudios sobre movimientos poéticos de vanguardia en España. Madrid: Gredos. 